\title{
Phytoprotection
}

\section{A potential microbial control for fireweed (Epilobium angustifolium)}

\author{
R.S. Winder et A.K. Watson
}

Volume 75, numéro 1, 1994

URI : https://id.erudit.org/iderudit/706049ar

DOI : https://doi.org/10.7202/706049ar

Aller au sommaire du numéro

Éditeur(s)

Société de protection des plantes du Québec (SPPQ)l

ISSN

0031-9511 (imprimé)

1710-1603 (numérique)

Découvrir la revue

Citer cet article

Winder, R. \& Watson, A. (1994). A potential microbial control for fireweed (Epilobium angustifolium). Phytoprotection, 75(1), 19-33.

https://doi.org/10.7202/706049ar
Résumé de l'article

Des plants infectés d'épi lobe à feuilles étroites (Epilobium angustifolium) ont été récoltés au Québec et les organismes isolés de ces plants ont été évalués comme agents potentiels de lutte biologique. Treize champignons pathogènes ont été isolés et trois d'entre eux (Colletotrichum dematium, Seimatosporium kriegerianum et Alternaria alternata) ont été virulents lors d'essais préliminaires de sélection. Le plus virulent de ceux-ci, $C$. dematium, a causé d'importantes lésions sur les feuilles et les tiges des plantes infectées et a été sélectionné pour une étude plus approfondie. La production d'inoculum a été optimale sur gélose à base d'extrait de malt modifié, et la virulence a été augmentée par l'enlèvement de la matrice des conidies à l'aide d'acide tannique et par l'addition d'extraits d'Aloe saponaria. La champignon a été pathogène pour l'épilobe à feuilles étroites et l'E. lanceolatum, alors que les autres espèces évaluées ont été résistantes ou immunisées. Les dimensions des conidies et des appressoria et le nombre restreint de plantes-hôtes supportent l'hypothèse que cet isolât pourrait être une forme-espèce non répertoriée. L'application d'une formulation de conidies âgées de 10 à $15 \mathrm{j}$, à une concentration de $10^{9}$ conidies $\mathrm{m}^{-2}$ et après une période de rosée de 18 à $24 \mathrm{~h}$, a causé la mortalité de 100\% des rosettes d'épilobe à feuilles étroites âgées de 7 semaines dans les $48 \mathrm{~h}$ suivant l'application. La virulence a été réduite chez les plantes plus âgées. Dans l'essai au champ, la croissance des rosettes infectées a diminué de $33 \%$. Ces résultats démontrent le potentiel de $C$. dematium comme agent de lutte biologique en sylviculture contre les plantules d'épilobe à feuilles étroites.
Ce document est protégé par la loi sur le droit d'auteur. L'utilisation des services d'Érudit (y compris la reproduction) est assujettie à sa politique d'utilisation que vous pouvez consulter en ligne.

https://apropos.erudit.org/fr/usagers/politique-dutilisation/ 


\title{
A potential microbial control for fireweed (Epilobium angustifolium)
}

\author{
Richard S. Winder ${ }^{1,2}$ and Alan K. Watson ${ }^{1}$
}

Received 1993-04-15; accepted 1993-12-24

Diseased fireweed (Epilobium angustifolium) plants were collected in Québec and organisms isolated from these plants were evaluated as potential biocontrol agents. Thirteen pathogenic fungi were isolated and three of these (Colletotrichum dematium, Seimatosporium kriegerianum, and Alternaria alternata) were virulent in initial screening assays. C. dematium was selected for further study because it was the most virulent pathogen, causing large necrotic lesions on leaves and stems of infected plants. Inoculum production was optimized on modified malt extract agar and the virulence enhanced by suppression of the conidial matrix with tannic acid and the addition of extracts of Aloe saponaria. The fungus was pathogenic to fireweed and E. lanceolatum, while other test species were very resistant or immune. Measurements of conidial and appressorial dimensions and its restricted host range support the hypothesis that the isolate may be an unreported form-species. Application of formulated conidia consistently provided $100 \%$ mortality of 7 -wk-old inoculated fireweed rosettes within $48 \mathrm{~h}$ using $10^{9}$ conidia $\mathrm{m}^{-2}$, from 10 - to 15-d-old inoculum, and a 18- to 24-h dew period. Virulence was diminished in older plants. In field trials, growth of inoculated rosettes was reduced by $33 \%$. These results suggest that $C$. dematium is a promising candidate for further development as a control agent for seedling fireweed in silviculture.

Winder, R.S. et A.K. Watson. 1994. Un agent potentiel pour la lutte microbienne contre l'épilobe (Epilobium angustifolium). PHYTOPROTECTION 75: 19-33.

Des plants infectés d'épilobe à feuilles étroites (Epilobium angustifolium) ont été récoltés au Québec et les organismes isolés de ces plants ont été évalués comme agents potentiels de lutte biologique. Treize champignons pathogènes ont été isolés et trois d'entre eux (Colletotrichum dematium, Seimatosporium kriegerianum et Alternaria alternata) ont été virulents lors d'essais préliminaires de sélection. Le plus virulent de ceux-ci, $C$. dematium, a causé d'importantes lésions sur les feuilles et les tiges des plantes infectées et a été sélectionné pour une étude plus approfondie. La production d'inoculum a été optimale sur gélose à base d'extrait de malt modifié, et la virulence a été augmentée par l'enlèvement de la matrice des conidies à l'aide d'acide tannique et par l'addition d'extraits d'Aloe saponaria. La champignon a été pathogène pour l'épilobe à feuilles étroites et l'E. lanceolatum, alors que les autres espèces évaluées ont été résistantes ou immunisées. Les dimensions

1. Department of Plant Science, Macdonald Campus of McGill University, 21111 Lakeshore Rd., Sainte-Anne-de-Bellevue, Québec, Canada H9X 3V9

2. Present address: Canadian Forest Service, Pacific Forestry Centre, 506 W. Burnside Rd., Victoria, British Columbia, Canada V8Z $1 \mathrm{M} 5$ 
des conidies et des appressoria et le nombre restreint de plantes-hôtes supportent I'hypothèse que cet isolat pourrait être une forme-espèce non répertoriée. L'application d'une formulation de conidies âgées de 10 à $15 \mathrm{j}$, à une concentration de $10^{9}$ conidies $\mathrm{m}^{-2}$ et après une période de rosée de 18 à $24 \mathrm{~h}$, a causé la mortalité de $100 \%$ des rosettes d'épilobe à feuilles étroites ágées de 7 semaines dans les $48 \mathrm{~h}$ suivant l'application. La virulence a été réduite chez les plantes plus âgées. Dans l'essai au champ, la croissance des rosettes infectées a diminué de $33 \%$. Ces résultats démontrent le potentiel de $C$. dematium comme agent de lutte biologique en sylviculture contre les plantules d'épilobe à feuilles étroites.

\section{INTRODUCTION}

Plants which colonize disturbed or logged areas help to begin the process of ecological succession which leads to a mature forest, but they can become major problems in reforestation programs. These pioneer plant species suppress the growth of tree crops through competition, allelopathy, and physical obstruction (Campbell 1990; Jobidon 1991; Lambert et al. 1969). Pioneer plants in the Onagraceae, including fireweed $(E$. angustifolium L. ssp. angustifolium) are major competing species in conifer reforestation areas. Fireweed is the earliest colonizer of burned-over and heavily clear-cut forests throughout boreal North America. It provides browse for wildlife and cattle, and has been used for medicinal purposes, as a honey plant, and as an ornamental, but it is also one of the most troublesome weeds in Canadian reforestation areas (Broderick 1990; Durand 1923; Haeussler and Coates 1986; Hultén 1968; Marie-Victorin 1964). In 1987, it infested $17 \%$ of the reforestation areas in the Matapédia region of Québec; the infestation was as much as $44 \%$ of vegetative cover in some areas (Gouvernement du Québec, Ministère de l'Énergie et des Ressources, Unité de Gestion Bas Saint-Laurent, unpublished data). Simazine [6-chloro- $N, N^{\prime}$ - diethyl-1,3,5-triazine-2,4-diamine], atrazine [6-chloro- $N$ ethyl- $N^{\prime}$-(1-methylethyl)-1,3,5-triazine-2,4diamine], EPTC [S-ethyldipropylcarbamothioate], glyphosate [N-(phosphonomethyl) glycine], and dicamba [3,6dichloro-2-methoxybenzoic acid] are some of the chemical herbicides used to control weeds of conifers, such as Epilobium spp. (Anonymous 1988; Campbell 1990; Haeussler and Coates 1986).
Because of public concerns regarding the indirect impacts of chemical pesticides in Canadian forests, research has started to focus on the need for other control options (Jobidon 1991).

Alternative control methods are particularly needed for fireweed. Epilobium spp. are prolific producers of air-borne seeds and can rapidly overtake an area, especially during hardening-off periods when tree seedlings can be sensitive to herbicides. Moreover, the hardy perennial rhizomes of fireweed make control by herbicides difficult and mechanical cultivation impractical (Haeussler and Coates 1986).

Several fungi have been proposed for control of reforestation weeds such as cherry (Prunus spp.) (de Jong et al. 1990; Wall 1985), raspberry (Rubus spp.) (J.R. Thibault, Université Laval, unpublished data) and other species (Wall 1990; Wall and Shamoun 1990). There are perhaps 20 to 40 fungi which have been reported on fireweed (Farr et al. 1989; Ginns 1986; Sinclair et al. 1987). The specific objectives of our study were to collect diseased fireweed, to isolate the causal organisms, and to assess the potential of selected fungal pathogens as potential biocontrol agents for this forestry weed problem.

\section{MATERIALS AND METHODS}

Diseased fireweed plants were collected in the Rimouski, Matapédia, and Beauce regions of Québec in July 1988, and in the La Tuque, Lac Saint-Jean, and Chicoutimi regions of Québec in July 1989. Pieces $(5 \mathrm{~mm} \times 5 \mathrm{~mm}$ ) of diseased tissue were immersed in $70 \%$ ethanol for 
$10 \mathrm{~s}$, transferred to $1.5 \% \mathrm{NaClO}$ for $4 \mathrm{~min}$, rinsed in two changes of sterile water, and placed in Petri plates containing potato dextrose agar (PDA). The plates were placed $28 \mathrm{~cm}$ under 40-W UV-A fluorescent lights with a $12 \mathrm{~h}$ on/off cycle and incubated for $10 \mathrm{~d}$ at $22^{\circ} \mathrm{C}$. Isolated fungi were aseptically transferred to PDA plates and the pure cultures were incubated in the above conditions. Six isolates of each fungus were transferred to PDA slants and incubated for $5 \mathrm{~d}$. About $10 \mathrm{~mL}$ of sterile paraffin oil was added to each vial, and the isolates were stored at $5^{\circ} \mathrm{C}$.

Local fireweed plant material used in the experiments originated from seeds collected in the Beauce region of Québec in 1988. For plant material assayed in the initial screening experiment, seeds were planted in 5-cm-diam pots containing a commercial potting mix (Promix, Premier Brands Ltd., Rivière-du-Loup, Québec), which were subsequently placed in a growth chamber [12-h photoperiod, photosynthetic photon flux density (PPFD) of $150 \mu \mathrm{mol} \mathrm{m} \mathrm{m}^{-2} \mathrm{~s}^{-1}, 24 / 18^{\circ} \mathrm{C}$ day/night temperature] for production of leaves, or in the greenhouse for production of whole plants. In subsequent experiments, seeds were germinated on agar in Petri dishes and germinated seeds were transferred to seed trays containing sand, pasteurized soil, and commercial potting mix $(1: 1: 1, v / v / v)$. After $3 w k$, the seedlings were transferred to individual $10-\mathrm{cm}$-diam pots containing the same soil mixture. Each pot was fertilized weekly with ca. $10 \mathrm{~mL}$ of solution containing $3 \mathrm{~g} \mathrm{~L}^{-1}$ of fertilizer (Plant Prod 20-20-20, Plant Products Ltd., Bramalea, Ontario). Plants were maintained in growth chambers with a 12-h photoperiod (PPFD of $300 \mu \mathrm{mol}$ $\mathrm{m}^{-2} \mathrm{~s}^{-1}$ ) and a $26 / 16^{\circ} \mathrm{C}$ day/night temperature.

Inoculum of Colletotrichum dematium (Pers. ex Fr.) Grove was produced on FMEA (fireweed extract plus malt extract agar), prepared by macerating $40 \mathrm{~g}$ of fireweed shoots in a blender (high speed for $30 \mathrm{~s}$ ) with $500 \mathrm{~mL}$ water and adding $45 \mathrm{~g}$ of dry malt extract agar and water sufficient for $1 \mathrm{~L}$ of medium prior to autoclaving. For bioassays, the cultures originated from storage vials. For all subsequent experiments, cultures of an isolate of C. dematium from Rimouski, Québec, were originated by re-isolation from inoculated plants in the whole plant bioassay and were maintained by continuous transfers from 10-d-old cultures on FMEA (primary FMEA cultures). Inocula for all experiments were collected from secondary FMEA cultures initiated by transfers from primary FMEA cultures which were incubated for $10 \mathrm{~d}$ with UV light (12-h daily photoperiod) at $22^{\circ} \mathrm{C}$.

The isolate was characterized by measuring conidial and appressorial dimensions. The length and width of 100 conidia from an FMEA culture were observed with a microscope and recorded. Conidial lengths were measured from base to apex, disregarding falcate curvature. Portions of leaves $(5 \mathrm{~mm} \times 5 \mathrm{~mm}$ ) from inoculated fireweed plants were placed between glass coverslips and slides with water and the dimensions of 100 darkly pigmented appressoria on the leaves were observed with a microscope and recorded. Where required in other experiments, estimates of conidial concentrations were obtained with the aid of a hemacytometer, using the mean of three measurements.

\section{Screening of fungal isolates}

Mycelia from the fungal isolates in storage vials were transferred to PDA plates and incubated for $10 \mathrm{~d}$ at $22^{\circ} \mathrm{C}$ as indicated above. Pathogenicity of these isolates was assessed using a detached leaf bioassay. Excised first leaves from 7-wk-old fireweed plants grown in the growth chamber were placed 3 per plate on moist filter paper in 9-cm-diam glass Petri plates. Inoculum of the fungal isolates was prepared by scraping conidia and hyphae from one culture into $50 \mathrm{~mL}$ of water plus $0.02 \%$ (vol/vol) surfactant (Tween 20, Fisher Scientific). The suspensions were applied to the excised leaves in an even coat with the bristles of an artist's round \#6 camel hair paintbrush. Inoculated detached leaves were incubated for $3 \mathrm{~d}$ at room temperature and effects were rated as 0 (no effect), 1 (slight damage), 2 (up to $10 \%$ damage), 3 (up to $50 \%$ damage), 4 (up to $100 \%$ damage).

Three fungi, Colletotrichum dematium, Seimatosporium kriegerianum (Bres.) Morgan-Jones \& Sutton in Sutton, and 
Alternaria alternata (Fries) Kiesler, which received a rating of 3 or above in the detached leaf bioassay were also examined in a whole plant bioassay. Five 10wk-old plants were sprayed with a $10^{7}$ conidia $\mathrm{mL}^{-1}$ suspension for each of the three fungi. Potted plants were sprayed in a spray chamber using a full cone nozzle (Tee-Jet Model TGO 7, Spraying Systems Co., Saskatoon, Saskatchewan), $180 \mathrm{kPa}$ pressure, $20 \mathrm{~cm}$ above the tops of the pots, in the equivalent volume of $500 \mathrm{~L}$ ha $^{-1}$. Sprayed pots were incubated for 18 $\mathrm{h}$ in a dark dew chamber at $21^{\circ} \mathrm{C}$ for 12 $h$, placed in the growth chamber under the above described conditions for $12 \mathrm{~h}$, and then returned to the dark dew chamber for an additional $12 \mathrm{~h}$. Pots were returned to the growth chamber and placed in a completely random design. After $3 d$, the extent of disease symptoms in the plants was observed and evaluated.

\section{Inoculum production}

The growth and sporulation of $C$. dematium, $S$. kriegerianum, and $A$. alternata were evaluated on six different solid agar media and four liquid media. The solid media included PDA, PDA plus fireweed, modified V8-juice agar (CZ8) (Winder and Van Dyke 1990), CZ8 with fireweed substituted for corn, malt extract agar (MEA), and FMEA. Media with fireweed were prepared with the same method used for FMEA. Agar plugs $\left(1 \mathrm{~cm}^{3}\right)$ were transferred from the stock cultures of the three fungi to five plates of each test medium. Inoculated plates were placed in a completely randomized design in an incubator with UV light (12-h daily photoperiod) at $22^{\circ} \mathrm{C}$. The radial growth of each colony was measured after $3 \mathrm{~d}$, and the data were subjected to analysis of variance (SAS Institute 1988). Because qualitative differences in sporulation were readily apparent, the sporulation of each colony was visually assessed after $3 \mathrm{~d}$ using a qualitative scale of 1 (sporulation sparse or lacking) to 4 (profuse sporulation throughout the entire colony).

The four liquid media were tested in a $2 \times 2$ factorial design for $C$. dematium only, with four replicates of each treatment. Each replicate was a flask containing $100 \mathrm{~mL}$ distilled water and $2 \mathrm{~g}$ of substrate. The type of substrate, glucose or malt extract, was the first factor. The presence or absence of $2 \%$ gelatin as a regulator of water potential was the second factor. Approximately $2 \times 10^{6}$ conidia scraped from uniformly sporulating cultures were inoculated into each flask and subsequently incubated for $9 \mathrm{~d}$ at room temperature (approximately $22^{\circ} \mathrm{C}$ ) on a rotary shaker (250 cycles $\left.\min ^{-1}\right)$. For each culture, net change in conidial number was estimated by comparing the estimated number of conidia introduced per flask with the final conidial concentration. The resulting conidial production data were subjected to analysis of variance (SAS Institute 1988). Each culture was classified as containing or lacking pigmented hyphae and the resulting data were subjected to a chisquared goodness of fit test, comparing against the expected occurrence of pigmented hyphae in all cultures. Four additional flasks containing $100 \mathrm{~mL}$ of the glucose/gelatin mixture were inoculated and incubated as described above. After incubation, the cultures were macerated in blender for $30 \mathrm{~s}$ at high speed, poured into 50 plastic Petri plates (9-cm diam) and incubated as in the FMEA method.

\section{Formulation}

A mixture of $0.5 \%(\mathrm{wt} / \mathrm{vol})$ malt extract, $0.5 \%(\mathrm{wt} / \mathrm{vol}$ ) yeast extract, $0.1 \mathrm{M} \mathrm{KCl}$, and $25 \%$ ( $\mathrm{vol} / \mathrm{vol})$ mesophyll of Aloe saponaria Haw., blended for $30 \mathrm{~s}$ and filtered through a nylon mesh (grid size $0.25 \mathrm{~mm}$ ), was utilized as a base formulation for subsequent conidial applications to plants. Conidial suspensions were prepared from twenty 10 -d-old FMEA cultures and the resulting $100 \mathrm{~mL}$ suspension was mixed with $500 \mathrm{~mL}$ of a $0.01 \mathrm{M}$ solution of tannic acid (mol wt 1701.18) for 4 min to bind matric proteins, as earlier observations indicated that the conidial matrix was inhibitory to conidial germination and difficult to remove by washing. The suspension was vacuum filtered with filter paper (Qualitative \#1, Whatman Int. Ltd.), scraped from the filter, and rinsed with brisk agitation in $500 \mathrm{~mL}$ distilled water. The inoculum was refiltered and combined with the base formulation solution to the desired concentration. The formulation was too viscous to be applied through 
the TGO 7 nozzles in the spray chamber and was subsequently applied to plants with a standard atomizer modified by mounting the nozzle vertically in a wooden frame. The downward-facing aperture of the nozzle was positioned 10 $\mathrm{cm}$ above the plants. Air pressure was supplied from a compressed air source and regulated with a valve. Plants at the 10 -wk-old stage or younger were treated using a 2-s burst. Older plants were turned vertically, placed $10 \mathrm{~cm}$ under the nozzle, and exposed to 2-s bursts for each uninoculated portion of the plant. Inoculum density was calculated from the flow rate for $2 \mathrm{~s}$ applied at a distance of $10 \mathrm{~cm}$.

\section{Host range testing}

The pathogenicity of $C$. dematium was tested on various collections of Epilobium angustifolium, other Epilobium species, three other Onagraceae species, and two representatives of two additional families (Table 3, page 28). Test plants in the three- to five-leaf stage were inoculated with the base formulation $\left(0\right.$ or $10^{9}$ conidia $\mathrm{m}^{-2}$ ) using the mounted atomizer, with a volume of $400 \mathrm{~L} \mathrm{ha}^{-1}$. Treated plants were placed in a dark dew chamber at $21^{\circ} \mathrm{C}$ for $18 \mathrm{~h}$, returned to the growth chamber, and arranged in a completely random design. There were six replicates for all test plants sprayed with the control treatment and eight replicates for all test plants treated with conidia. After $1 \mathrm{wk}$ of growth chamber incubation, plants were visually rated; plants with necrotic lesions were rated susceptible, plants with small chlorotic or necrotic flecks as resistant, and those with no reaction as immune. In resistant and immune plants, $5 \mathrm{~mm} \times 5 \mathrm{~mm}$ portions of treated leaves were excised and mounted with water between glass coverslips and slides and examined with the aid of microscope. The location of the defense response was characterized as either internal or external by noting the extent to which the leaf tissue was colonized. If appressoria did not form or cause any discoloration of host tissue, or if conidia did not germinate, the defense response was categorized as external. If appressoria occasionally caused discoloration limited to immediately underlying host cells, the defense response was categorized as internal.

\section{Weed control efficacy}

The effects of inoculum density, inoculum age, dew period duration, and plant age on the virulence of the $C$. dematium isolate were assessed in four separate experiments with five replicates per treatment. The experiments were conducted in growth chambers in a general randomized block design (Addeman 1969). Unless otherwise stated, inoculations were conducted with 7-wk-old plants in the rosette stage, $10^{9}$ formulated conidia $\mathrm{m}^{-2}, 10$-d-old FMEA cultures, and a subsequent dark dew period at $21^{\circ} \mathrm{C}$ for 18 $\mathrm{h}$ prior to placement of treated plants in the growth chamber. To assess the effect of inoculum density, the plants were inoculated with $0,10^{6}, 10^{7}, 10^{8}$, and $10^{9}$ conidia $\mathrm{m}^{-2}$. To assess the effect of inoculum age, plants were inoculated with conidia from 10-, 15-, and 20-d-old FMEA cultures. To assess the effect of dew period duration, plants were inoculated and subsequently incubated for 0 , $6,12,18,24,30$, and $36 \mathrm{~h}$ in a dark dew chamber at $21^{\circ} \mathrm{C}$. Replication for the dew period was reduced to four spatial replications per treatment to conserve space. To assess the effect of plant age, plants at the 7-wk-old (rosette), 10-wk-old (elongation), and 13-wk-old (flowering) stages were tested. Each of the above experiments was repeated twice, spaced $1 \mathrm{wk}$ apart and treated as blocks corresponding to the three separate trials. The percentage of leaf area damaged (\%LAD) on each plant was visually rated $48 \mathrm{~h}$ after inoculation.

Bartlett's test (Steel and Torrie 1980) indicated significant heterogeneity of variance, which was corrected by transformation using the logarithm of the quantity (\%LAD +1$)$; a standard arcsin transformation was not used because it did not correct the heterogeneity. To facilitate analysis, treatments with 0 conidia $\mathrm{m}^{-2}$ were treated as 1 conidium $\mathrm{m}^{-2}$. The transformed data were analyzed (SAS Institute 1988) to form regression models of treatment effects. Where the number of treatments permitted it, models using polynomials of up to third order were tested. In each case, the best model was deemed to be the one that had no non-significant terms and the highest $R^{2}$ value. The transformed data were tabulated for more direct and simple 
comparison with the original, untransformed means.

\section{Field trials}

The virulence of the Rimouski isolate of C. dematium was assessed at the Emile Lods Agronomy Research Centre, Macdonald Campus of McGill University, Sainte-Anne-de-Bellevue, Québec. Trials were arranged in a completely randomized block design, with four $2 \mathrm{~m} \times 2 \mathrm{~m}$ plots for each treatment. There were three treatments for each of four blocks arranged to compensate for potential soil heterogeneity. On 28 August 1990, 10 -wk-old fireweed rosettes were transplanted 16 per plot into a uniform $4 \times 4$ grid with a $40 \mathrm{~cm}$ space between each plant and its neighbor or the edge of the plot. All of the plots were arranged in a rectangular grid $1 \mathrm{~m}$ apart, with a $1 \mathrm{~m}$ border around the entire grid.

Inoculum with a concentration of $10^{8}$ conidia $\mathrm{mL}^{-1}$ was applied in the evening at a rate of $10^{9}$ conidia $\mathrm{m}^{-2}\left(100 \mathrm{~L} \mathrm{ha}^{-1}\right)$ with an atomizer. The three treatments consisted of a control with formulation solution only, one application of conidia on 12 September 1990, or two conidial applications: one on 12 September 1990 and one on 27 September 1990. The height (soil to highest point) and diameter (longest horizontal line between leaf tips) of each plant was recorded before application. The same measurements were recorded on 14 October, when \%LAD was estimated for each plant and the shoots were harvested from the soil line. The fresh weight of each plant was recorded; dry weights were recorded after drying the shoots at $40^{\circ} \mathrm{C}$ for $9 \mathrm{~d}$ in an oven. Plant growth was estimated by calculating the difference between plant sizes before application and size at the time of rating. Fireweed has a conical morphology, so size was determined by calculating the volume of a cone as in Eq. [1], where $h=$ height and $d=$ diameter:

$$
0.5\left(h \pi\left(0.5 d^{2}\right)\right)
$$

Because of the heterogeneity of final plant sizes and the effect of plant size on susceptibility, it was necessary to analyze the data using original plant size as a covariate in analysis of covariance (SAS Institute 1988). Means were adjusted using the least squares method. Visual estimates of $\%$ LAD were not transformed because Bartlett's test indicated that the variances were homogeneous.

\section{RESULTS AND DISCUSSION}

\section{Isolation and screening of isolates}

Thirteen fungi were isolated from diseased fireweed collected in Québec (Table 1). Pucciniastrum spp., S. kriegerianum and Ramularia montana Speg. have previously been reported from fireweed (Farr et al. 1989; Ginns 1986; Sinclair et al. 1987). Pucciniastrum spp. and $A$. alternata were the only two pathogens observed in 1989, possibly because of differences in climate and geography between the two surveys.

In the detached leaf assay, $A$. alternata, Candida sp., Colletotrichum dematium, $S$. kriegerianum, and $R$. montana caused visible damage (Table 1). In the whole plant bioassay, $C$. dematium and $S$. kriegerianum produced leaf and stem lesions similar to those observed in the field. Both pathogens were re-isolated from inoculated plants, fulfilling Koch's postulates (Tuite 1969). C. dematium affected the entire plant, whereas the effect of $S$. kriegerianum was more localized.

Conidia of the Rimouski isolate of $C$. dematium were falcate, $2.6 \pm 0.1 \mu \mathrm{m}$ wide (range: $2-3 \mu \mathrm{m}$ ) and $25.2 \pm 0.4 \mu \mathrm{m}$ long (range: $20.5-30.0 \mu \mathrm{m}$ ). Appressoria were multilobate, $5.8 \pm 0.2 \mu \mathrm{m}$ wide (range: 6.0-11.0 $\mu \mathrm{m}$ ) and $8.0 \pm 0.3 \mu \mathrm{m}$ long (range: 4.0-9.0 $\mu \mathrm{m}$ ). No reports were found of form-species of $C$. dematium isolated from the Onagraceae with these characteristics. The possibility that the fireweed isolate of $C$. dematium is a forma specialis is also supported by the host range information. Further studies on host range and morphological comparisons amongst other isolates are necessary to propose a forma specialis.

\section{Inoculum production}

In general, addition of fireweed tissue to the medium resulted in faster fungal growth. The best solid agar medium for producing inoculum of $C$. dematium was FMEA (Table 2). S. kriegerianum grew very slowly compared to the other fungi; 
Table 1. Origin and pathogenicity of fungi from fireweed in Québec

\begin{tabular}{|c|c|c|c|}
\hline Species & $\begin{array}{c}\text { Origin } \\
\text { of isolates }^{\text {a }}\end{array}$ & $\begin{array}{l}\text { Lesion } \\
\text { type }^{b}\end{array}$ & $\begin{array}{c}\text { Detached } \\
\text { leaf } \\
\text { assayc }^{c}\end{array}$ \\
\hline Alternaria alternata & $R, B(3), L T, L S, C$ & LB & 4 \\
\hline Candida sp. & $B(2)$ & $\mathrm{SC}$ & 2 \\
\hline Colletotrichum dematium & $R, B$ & LT & $3-4$ \\
\hline Epicoccum sp. & B & LT & - \\
\hline Fusarium sp. & B & $\mathrm{RR}$ & - \\
\hline Gliocephalis sp. & M & LT & 0 \\
\hline Penicillium sp. & $\mathrm{R}, \mathrm{B}$ & LT, SC & - \\
\hline Phomopsis sp. & B & LT & - \\
\hline Pucciniastrum spp. & $B, L T, L S, C$ & SR & - \\
\hline Ramularia montana & $R, B$ & $L T, S C$ & 1 \\
\hline Seimatosporium kriegerianum & $R(2), B$ & SC & $0-3$ \\
\hline Sordaria sp. & B & LT & 0 \\
\hline Trichoderma sp. & B & $\mathrm{RR}$ & - \\
\hline
\end{tabular}

a Abbreviations for origins: $\mathrm{R}=$ Rimouski (1988); $\mathrm{M}$ = Matapédia valley (1988); $\mathrm{B}=$ Beauce valley (1988); LT = La Tuque (1989); LS = Lac Saint Jean (1989); C = Chicoutimi (1989). If more than one isolate was found, the number appears by the code in parentheses.

b Abbreviations for the types of lesions associated with the fungus in the field: $L B=$ large, darkbrown lesions surrounded by a yellow discoloration; $L T=$ large, $\tan$ lesions surrounded by a magenta discoloration; $\mathrm{SC}=$ small, circular lesions similar to type $\mathrm{LT} ; \mathrm{SR}=$ small red flecks, $\mathrm{RR}=$ rhizome rot.

c Detached leaf rating: - = not tested; $0=$ no effect; $1=$ up to $1 \%$ leaf area necrotic; $2=$ up to $10 \%$ leaf area necrotic; $3=$ up to $50 \%$ leaf area necrotic; and $4=$ up to $100 \%$ leaf area necrotic. The range of reactions for three leaf pieces is shown.

Table 2. Growth and sporulation of three fireweed pathogens on six solid agar media

\begin{tabular}{|c|c|c|c|c|c|c|}
\hline \multirow{2}{*}{$\begin{array}{l}\text { Agar } \\
\text { medium }\end{array}$} & \multicolumn{3}{|c|}{$\begin{array}{l}\text { Growth }^{a} \\
\left(\mathrm{~mm} \mathrm{~d}^{-1}\right)\end{array}$} & \multicolumn{3}{|c|}{$\begin{array}{c}\text { Sporulation } \\
\text { rating }^{b}\end{array}$} \\
\hline & $\mathrm{Aa}$ & $\mathrm{Cd}$ & Sk & $\overline{\mathrm{Aa}}$ & $\mathrm{Cd}$ & $\overline{\mathrm{Sk}}$ \\
\hline Potato dextrose (PD) & $1.8 \mathrm{a}$ & $1.7 \mathrm{a}$ & $0.8 \mathrm{~b}$ & 3 & 1 & 2 \\
\hline$P D$ + fireweed & $3.2 \mathrm{~b}$ & $2.7 \mathrm{~b}$ & $0.6 a b$ & 3 & 2 & 2 \\
\hline Corn/V8-juice (CV) & $1.9 \mathrm{a}$ & $1.7 \mathrm{a}$ & $0.6 \mathrm{ab}$ & 0 & 1 & 0 \\
\hline$C V+$ fireweed & $2.7 \mathrm{bc}$ & $2.6 \mathrm{~b}$ & $0.5 \mathrm{a}$ & 1 & 1 & 0 \\
\hline Malt extract (ME) & $2.5 \mathrm{~b}$ & $2.7 \mathrm{~b}$ & $0.7 \mathrm{ab}$ & 2 & 2 & 1 \\
\hline$M E$ + fireweed & $2.8 \mathrm{c}$ & $2.7 \mathrm{~b}$ & $1.0 \mathrm{~b}$ & 2 & 3 & 2 \\
\hline
\end{tabular}

a Means of five plates are shown. Those followed by the same letter in the same column are not significantly different, with $\operatorname{LSD}(0.05)=0.2$. Species abbreviations are: $A a=$ Alternaria alternata, $\mathrm{Cd}=$ Colletotrichum dematium, and $\mathrm{Sk}=$ Seimatosporium kriegerianum .

b Sporulation ratings were the same for each plate in each treatment, hence no variability is shown. The ratings are: $0=$ sporulation absent or nearly absent; $1=$ sparse sporulation; 2 = light sporulation; and 3 = heavy sporulation. 
rearing it for inoculum would require special techniques (Table 2). These results, combined with the results from the whole plant comparison, were the basis for continued evaluation of $C$. dematium. The selection of $C$. dematium was also supported by the demonstrated utility of Colletotrichum species in other inundative biocontrol research programs (Anderson and Walker 1985; Boyette 1991; Boyette et al. 1979; Hildebrand and Jensen 1991; McRae and Stevens 1990; Mortensen 1988; Smith 1986; Trujillo et al. 1986; Wymore et al. 1988).

Growth of $C$. dematium in the liquid cultures tested was almost entirely vegetative with limited sporulation as approximately $50 \%$ of the original inoculum was recovered in the malt extract and 50 to $100 \%$ in the glucose cultures (data not shown). The only conidiogenesis observed occurred in acervuli located near the surface of the liquid cultures. These acervuli were scattered throughout the dense ring-shaped mat of hyphae attached to the flask sides at the mediumair interface. Sclerotia typically formed throughout the rest of the culture. In the malt extract medium, only sclerotia were formed. Malt extract favored hyphal growth whereas glucose provided some, but limited, conidiogenesis. Since FMEA was the best solid medium for sporulation of this isolate, the absence of a solid matrix appeared to be a limiting factor. While gelatin was inhibitory in preliminary spore germination assays (data not shown), the addition of $2 \%$ gelatin did not significantly inhibit germination in the liquid systems. Addition of protein (gelatin) reduced hyphal pigmentation. There were no pigmented hyphae in the cultures containing gelatin, while hyphae were dark brown when gelatin was absent.

In the supplementary UV light experiment, liquid glucose-gelatin cultures dispensed into plastic Petri dishes produced abundant sclerotia without exception; the level of production was much more dense compared with the production of acervuli or sclerotia in the absence of this additional step. Further modifications will be necessary before conidial mass production of this isolate in liquid culture is feasible. Conidial production methods will have to more closely approach the conditions present in a typical sporulating colony grown on FMEA under UV light. Solid culture media or the use of hyphal formulations are options that might be considered.

\section{Formulation}

When conidia of $C$. dematium were combined with the Aloe saponaria extract, consistent excellent control $(100 \%$ mortality within 48 h) of fireweed was obtained (Fig. 1). The Aloe extract alone had no effect, suggesting that its role was augmentative and non-toxic. Leaf extracts from Aloe contain variable amounts of proteins, carbohydrates, and other secondary compounds (Conner et al. 1989; Mabusela et al. 1990). The role of these compounds in the formulation may have been to serve as an inhibitorfree surrogate matrix, but some compounds, particularly pectins, can also have unique properties which facilitate pathogenesis (Boyette 1987). A surrogate matrix would provide adhesion, protection from desiccation, and various other pathogenic functions (McRae and Stevens 1990). It could also bind to inhibitory phenolic compounds on the leaf surface (Nicholson et al. 1989). Regarding the other formulation components, the stimulatory effects of malt extract and yeast extract on appressorium formation have previously been reported (Grover 1971).

Other experiments have detected a potent phytotoxin from this isolate (A. K. Watson, unpublished data). It could be that this toxin is responsible for the rapid mortality. By way of comparison, esters of epoxydecatrienoic acid produced by germinating conidia of Alternaria alternata $f$. sp. kikuchiana, known collectively as AK-toxin, can cause necrosis within $20 \mathrm{~h}$, disrupting ca. 100 plant cells per conidium (Nishimura and Kohmoto 1983). The mode of pathogenesis described for this isolate of $C$. dematium appears to be a variation of the necrotrophic mode, in which an inundation of conidia causes enough advance necrosis to overwhelm the entire plant. The effectiveriess of this mode may explain why so many Colletotrichum spp. are being studied as potential biocontrol agents.

The dramatic improvement of efficacy, from insignificant damage in initial 
screening to consistent mortality after formulation, has interesting implications for mycoherbicide screening and formulation strategies. For fungi such as $C$. dematium, potential efficacy at high doses may be restricted by matric regulation (Louise et al. 1988; Sparace et al. 1991) and could be much higher than preliminary assays would indicate. For other species, it has been reported that matric enzymes enhance virulence (Nicholson et al. 1989). Improved screening methods should take such qualitative details of disease ontogeny into account, rather than simply focusing on quantitative data. Formulation of inoculum mass-produced in liquid culture would be improved if the presence or absence of key matric properties could be ensured.

\section{Host range}

All collections of $E$. angustifolium (fireweed) and $E$. lanceolatum Sub. were susceptible to C.dematium, E. glandulosum
Lehmann, E. coloratum Biehler, and Abutilon theophrasti Medic. were resistant, and all other plants tested were immune (Table 3). The $C$. dematium isolate from fireweed appears to be host specific and restricted to Epilobium angustifolium and possibly a few closely related Epilobium species. Further host specificity studies are necessary to accurately determine the limits of this pathogen and to ensure that the isolate is not pathogenic to desirable conifers and other forest flora.

\section{Weed control efficacy}

Transformed \%LAD (T\%LAD) increased exponentially with the log of conidial concentration, with uninoculated plants remaining unaffected (Table 4). Significant $(P<0.02)$ differences between the three trials in this experiment and the inoculum age experiment could be due to variations in inoculum virulence or uncontrolled environmental factors such

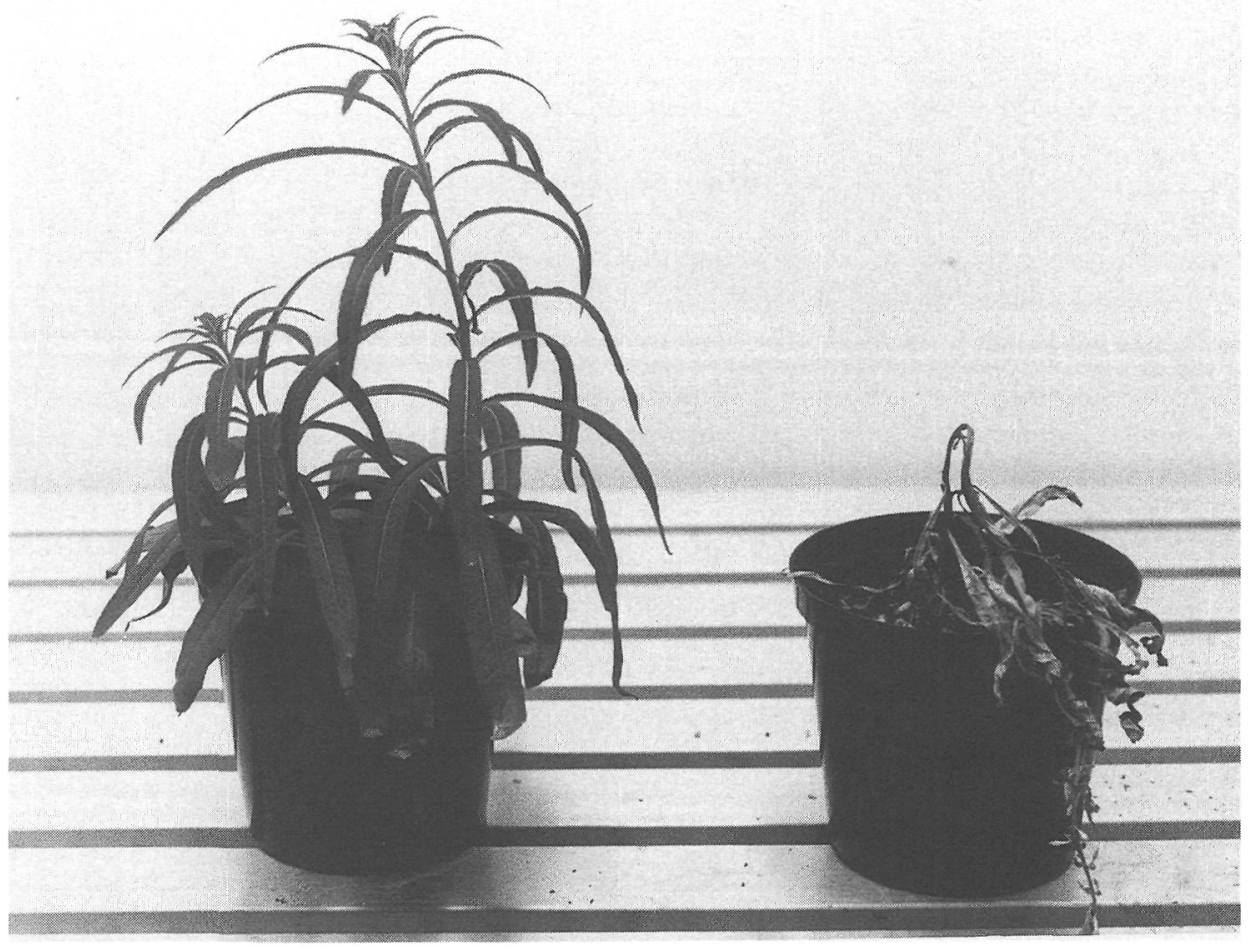

Figure 1. Effect of $10^{9}$ conidia $\mathrm{m}^{-2}$ of Colletotrichum dematium applied to 13-wk-old fireweed. Plants were subsequently exposed to a 24-h dew period. The photograph was taken $24 \mathrm{~h}$ after inoculation. The adjuvant control is on the left and fungal treatment is on the right. 
as humidity. The regression model which resulted in the best fit for virulence in terms of dosage $\left(R^{2}=0.81\right)$ is shown in Eq. [2],

$$
\begin{gathered}
\text { T\%LAD }=-0.22+t-(0.88 \text { dose }) \\
+\left(0.25 \text { dose }^{2}\right)-\left(0.13 \text { dose }^{3}\right)
\end{gathered}
$$

where tequals $0.11,0.22$, and 0.33 for the first, second, and third trials, respectively. This model indicates that dosages higher than $10^{9}$ conidia $\mathrm{m}^{-2}$ might achieve greater damage.

There was no significant regression trend for damage versus inoculum age (Table 5). A $R^{2}$ value of 0.28 was obtained for the regression model which best fit the data, shown in Eq. [3],

$\mathrm{T} \% \mathrm{LAD}=2.37+\mathrm{t}-(0.02$ age $)$

where $t$ values were the same as those given for the inoculum density experiment. Damage from 20-d-old cultures was significantly lower than damage from younger cultures in only one of the three trials (Table 5). Shelf-life could be limited for some batches of inoculum, or the inconsistent virulence may simply be due to variability of media or other batch effects. There were also highly significant differences $(P<0.005)$ between trials in this experiment.

Table 3. Pathogenicity of the fireweed isolate of Colletotrichum dematium on some plant

\begin{tabular}{|c|c|c|c|}
\hline \multirow[b]{2}{*}{ Host name and taxon } & \multirow[b]{2}{*}{ Seed source ${ }^{a}$} & \multicolumn{2}{|c|}{ Host response ${ }^{b}$} \\
\hline & & Trial 1 & Trial 2 \\
\hline \multicolumn{4}{|l|}{ Myrtales (Onagraceae): } \\
\hline $\begin{array}{l}\text { Epilobium angustifolium } \\
\text { ssp. angustifolium }\end{array}$ & Rimouski, Québec & $\mathrm{S}$ & S \\
\hline $\begin{array}{l}\text { E. angustifolium } \\
\text { ssp. angustifolium }\end{array}$ & Beauce, Québec & $S$ & S \\
\hline $\begin{array}{l}\text { E. angustifolium } \\
\text { ssp. angustifolium }\end{array}$ & $\begin{array}{l}\text { Riviere Verte, } \\
\text { New Brunswick }\end{array}$ & $S$ & \\
\hline $\begin{array}{l}\text { E. angustifolium } \\
\text { ssp. angustifolium }\end{array}$ & Nantes, France & $\mathrm{S}$ & \\
\hline E. angustifolium ssp. album & Chicoutimi, Québec & $\mathrm{S}$ & \\
\hline E. coloratum Biehler & Montréal, Québec & IR & $\|$ \\
\hline E. glandulosum Lehm. & Montréal, Québec & ER & \\
\hline E. lanceolatum Sub. & Nantes, France & $\mathrm{S}$ & \\
\hline E. montanum L. & Nantes, France & El & $\mathrm{IR}$ \\
\hline Circea lutetiana L. & Nantes, France & ॥ & \\
\hline Oenothera parviflora L. & Montréal, Québec & $\|$ & $\mathrm{EI}$ \\
\hline O. perennis $\mathrm{L}$. & Montréal, Québec & ॥ & El \\
\hline \multicolumn{4}{|l|}{ Myrtales (Lythraceae): } \\
\hline Lythrum salicaria L. & Île Perrot, Québec & ॥ & \\
\hline \multicolumn{4}{|l|}{ Malvales (Malvaceae): } \\
\hline Abutilon theophrasti Medic. & $\begin{array}{l}\text { McGill University, } \\
\text { Québec }\end{array}$ & $\mathrm{R}$ & \\
\hline
\end{tabular}
species

a Seeds from Montréal were obtained from the Montréal Botanical Garden; those from Nantes were obtained from the Nantes Botanical Garden.

b Abbreviations for assay reaction results after 1 wk incubation are: $S=$ susceptible; $E R=$ external resistance; $\mathbb{I R}=$ internal resistance; $R=$ externally and internally resistant; $\mathrm{EI}=$ externally immune, and $\|$ = internally immune. 
WINDER, WATSON: MICROBIAL FIREWEED CONTROL

Table 4. Effect of inoculum density of Colletotrichum dematium on disease expression on inoculated fireweed

\begin{tabular}{|c|c|c|c|c|c|c|}
\hline \multirow{2}{*}{$\begin{array}{l}\quad \log \\
\text { (conidia } \mathrm{m}^{-2} \text { ) }\end{array}$} & \multicolumn{3}{|c|}{ Mean \%LAD ${ }^{a}$} & \multicolumn{3}{|c|}{$\mathrm{T} \% \mathrm{LAD}^{\mathrm{b}}(\overline{\mathrm{X}} \pm \mathrm{SD})$} \\
\hline & 1 & 2 & 3 & 1 & 2 & 3 \\
\hline 0 & 0 & 0 & 0 & $0 \pm 0$ & $0 \pm 0$ & $0 \pm 0$ \\
\hline 6 & 0.7 & 2.7 & 4.9 & $0.17 \pm 0.07$ & $0.45 \pm 0.08$ & $0.60 \pm 0.08$ \\
\hline 7 & 4.8 & 5.8 & 25.9 & $0.78 \pm 0.26$ & $0.79 \pm 0.26$ & $1.45 \pm 0.08$ \\
\hline 8 & 42.7 & 37.9 & 52.7 & $1.64 \pm 0.13$ & $1.59 \pm 0.26$ & $1.73 \pm 0.05$ \\
\hline 9 & 96.7 & 49.1 & 84.1 & $1.99 \pm 0.25$ & $1.99 \pm 0.12$ & $1.71 \pm 0.03$ \\
\hline
\end{tabular}

a $\quad \mathrm{LAD}=$ leaf area damaged. The means of three separate trials are compared. Plants in the 7wk-old rosette stage were subjected to an $18 \mathrm{~h}$-dew period subsequent to treatment, with five replicates per treatment.

b Transformed means are calculated as $\log (\% \operatorname{LAD}+1)$.

Table 5. Effect of inoculum age of Colletotrichum dematium on disease expression on inoculated fireweed

\begin{tabular}{|c|c|c|c|c|c|c|}
\hline \multirow{2}{*}{$\begin{array}{l}\text { Inoculum } \\
\text { age } \\
\text { (d) }\end{array}$} & \multicolumn{3}{|c|}{ Mean \%LAD } & \multicolumn{3}{|c|}{$\mathrm{T}_{\mathrm{L}} \mathrm{LAD}^{\mathrm{b}}(\overline{\mathrm{X}} \pm \mathrm{SD})$} \\
\hline & 1 & 2 & 3 & 1 & 2 & 3 \\
\hline 10 & 86.1 & 78.4 & 74.9 & $1.94 \pm 0.02$ & $1.91 \pm 0.13$ & $1.88 \pm 0.04$ \\
\hline 15 & 78.4 & 69.8 & 78.4 & $1.91 \pm 0.02$ & $1.87 \pm 0.03$ & $1.91 \pm 0.02$ \\
\hline 20 & 94.5 & 94.5 & 24.7 & $1.98 \pm 0.30$ & $1.98 \pm 0.01$ & $1.42 \pm 0.11$ \\
\hline
\end{tabular}

a $L A D=$ leaf area damaged. The means of three separate trials are compared. Plants in the 7wk-old rosette stage were treated with $10^{9}$ conidia $\mathrm{m}^{-2}$ and subsequently subjected to an 18$\mathrm{h}$ dew period, with five replicates per treatment.

b Transformed means are calculated as $\log (\% \operatorname{LAD}+1)$.

Damage increased exponentially with dew period; the regression model which best fit the data is shown in Eq. [4],

$$
\begin{aligned}
& \text { T\%LAD }=0.07-(0.13 d)+\left(0.03 d^{2}\right) \\
& -\left(0.001 d^{3}\right)+\left(0.00002 d^{4}\right)
\end{aligned}
$$

with d equal to the dew period $\left(R^{2}=0.93\right)$. Dew periods of $24 \mathrm{~h}$ or more were almost always lethal (Table 6). Significant damage first appeared at $12 \mathrm{~h}$; mean T\%LAD markedly increased from 0.11 in the $6-h$ treatment to 0.91 in the 12-h treatment. T\%LAD continued to increase to 1.91 by $18 \mathrm{~h}$; the interval of 6-18 $\mathrm{h}$ appears to correspond to the likely duration of a nocturnal dew period.

Damage decreased with plant age; the best-fitting regression model was the linear reduction shown in Eq.[5],
T\%LAD $=3.18-(0.19$ age $)$

where $R^{2}=0.69$. These data indicate that young fireweed seedlings are more susceptible to $C$. dematium than older plants (Table 7). The regression model indicates that plants less than $7 \mathrm{wk}$ old could be more susceptible than any of the plants tested. Conversely, plants older than 13 wk could be more resistant than any of the plants tested. The larger upper leaves of older plants appeared to interfere with treatments by collapsing onto lower leaves, preventing their full inoculation. Water also accumulated at the apices of larger leaves, resulting in redistribution of inoculum.

The optimum effect of $C$. dematium would be on plants at the rosette stage with $10^{9}$ conidia $\mathrm{m}^{-2}$ from 10 - to 15 -d-old 
Table 6. Effect of duration of dew period on Colletotrichum dematium disease expression on inoculated fireweed

\begin{tabular}{ccl}
\hline $\begin{array}{c}\text { Dew period } \\
(\mathrm{h})\end{array}$ & Mean \%LAD & $\begin{array}{l}\text { T\%LAD }^{\mathrm{b}} \\
(\overline{\mathrm{X}} \pm \mathrm{SD})\end{array}$ \\
\hline 0 & 0.1 & $0.04 \pm 0.02$ \\
6 & 0.3 & $0.11 \pm 0.03$ \\
12 & 7.1 & $0.91 \pm 0.10$ \\
18 & 79.4 & $1.91 \pm 0.03$ \\
24 & 100.0 & $2.00 \pm 0$ \\
30 & 95.5 & $1.98 \pm 0.02$ \\
36 & 100.0 & $2.00 \pm 0$ \\
\hline
\end{tabular}

a $L A D=$ leaf area damaged. Plants in the 7 -wk-old rosette stage were treated with $10^{9}$ conidia $\mathrm{m}^{-2}$, with four replicates per treatment.

b Transformed means are calculated as log $(\% \operatorname{LAD}+1)$.

Table 7. The effect of plant age on disease expression of Colletotrichum dematium on inoculated fireweed

\begin{tabular}{ccc}
\hline $\begin{array}{c}\text { Plant age } \\
(w \mathrm{wk})\end{array}$ & Mean \%LAD & $\begin{array}{c}\text { T\%LAD } \\
(\overline{\mathrm{X}} \pm \mathrm{SD})\end{array}$ \\
\hline 7 & 45.8 & $1.67 \pm 0.05$ \\
10 & 28.5 & $1.47 \pm 0.09$ \\
13 & 5.0 & $0.78 \pm 0.09$ \\
\hline
\end{tabular}

a $\mathrm{LAD}=$ leaf area damaged. Plants were treated with $10^{9}$ conidia $\mathrm{m}^{-2}$ and subsequently subjected to an $18 \mathrm{~h}$-dew period, with five replicates per treatment.

b Transformed means are calculated as log (\%LAD + 1).

Table 8. Response of field-grown fireweed to applications of conidia of Colletotrichum dematium

\begin{tabular}{|c|c|c|c|c|c|c|}
\hline \multirow[b]{2}{*}{ Parameter } & \multicolumn{3}{|c|}{ Adjusted mean ${ }^{a}$} & \multicolumn{3}{|c|}{$\%$ success $^{b}$} \\
\hline & $0 \times$ & $1 \times$ & $2 \times$ & $0 \times$ & $1 \times$ & $2 x$ \\
\hline $\begin{array}{l}\text { Fresh weight plant }{ }^{-1} \\
\text { (g) }\end{array}$ & $5.5 \mathrm{a}^{\mathrm{c}}$ & $5.0 \mathrm{a}$ & $4.9 \mathrm{a}$ & 100.0 & 90.9 & 89.1 \\
\hline $\begin{array}{l}\text { Dry weight plant }{ }^{-1} \\
\text { (g) }\end{array}$ & $1.2 \mathrm{a}$ & $1.1 \mathrm{a}$ & $1.2 \mathrm{a}$ & 100.0 & 91.6 & 100.0 \\
\hline $\begin{array}{l}\text { Leaf area damage } \\
(\%)\end{array}$ & $4.4 \mathrm{a}$ & $12.6 \mathrm{~b}$ & $14.9 \mathrm{~b}$ & 95.6 & 91.7 & 89.5 \\
\hline $\begin{array}{l}\text { Growth plant }{ }^{-1} \\
\left(\mathrm{dm}^{3}\right)\end{array}$ & $2.7 \mathrm{a}$ & $2.0 \mathrm{ab}$ & $1.8 \mathrm{~b}$ & 100.0 & 74.1 & 66.6 \\
\hline
\end{tabular}

a Abbreviations for treatments are: $0 x=$ control spray, $1 x=1$ spray application; $2 x=2$ spray applications spaced $2 \mathrm{wk}$ apart. Conidial concentration was $10^{8}$ conidia $\mathrm{mL}^{-1}$, applied at a rate of $100 \mathrm{~L} \mathrm{ha}^{-1}$ with an atomizer.

b Fireweed success was calculated as a percentage of the unsprayed control or, in the case of damage, an ideal $(100 \%$ undamaged) plant.

c Adjusted means followed by the same letter in the same row are not significantly different $(P>0.05)$ using contrasts from the least square means methods. 
cultures, using a dew period of up to 24 $\mathrm{h}$. The optimal concentration is about 10 to 100 times higher than optima reported for tests of Colletotrichum spp. on other weed species (Smith 1986; Wymore et al. 1988) but such high rates may be necessary to achieve the very rapid destruction of tissue.

\section{Field trials}

C. dematium reduced the vigor of fireweed in the field (Table 8). There was a significant increase in adjusted mean $\%$ LAD, from $4.4 \%$ in controls (representing senescence and herbivory) to $14.9 \%$ with two inoculations. Two inoculations of $C$. dematium inhibited growth by one third in terms of the adjusted mean change in size $(P<0.05)$ (Table 8). Despite the significant damage and reduction of vigor, the lower adjusted mean fresh and dry weight of inoculated plants was not significantly different than controls $(P>0.05)$. The period after inoculation was too short for the production of weight differences which could be separated from variance in the field. There were several factors which limited damage in the field. Subsequent to both applications, the nightly dew necessary for germination of conidia was only observed in the lower $10-$ to $20-\mathrm{cm}$ portion of each plant. These dew periods were also relatively short $(12 \mathrm{~h})$ in duration. The mean adjusted \%LAD caused by a single application in the field minus control \%LAD was $8.2 \%$, which is consistent with the earlier growth chamber observations for the same dew period (LAD = $7.1 \%)$. Additionally, there was sporadic bolting of seedlings from the rosette stage to the more resistant flowering stage. The damage to smaller plants was fairly consistent with the earlier growth chamber observations.

\section{Biocontrol potential}

The complete elimination of competing vegetation is increasingly being viewed as an unwise silvicultural practice (Wagner and Zasada 1991). When tree crops are released from competition, vegetation that was once detrimental promotes the integrity of a new forest through beneficial effects ranging from control of soil erosion or nutrients and cooler temperatures to the reduction of other pest problems (Haeussler and Coates 1986). C. dematium could potentially fit into this phase of forest regeneration as a microbial control agent capable of limiting competition from fireweed without completely removing it from the site. There are several points to consider at this stage of research. Optimum largescale inoculum production and formulation will require modifications, including a less viscous solution, a method for producing conidia in liquid culture, and a thorough investigation of host specificity and the extent of naturally occurring variability. Performance and reliability would be enhanced with formulations that do not require dew (Daigle et al. 1990). Other parameters, such as temperature (Wymore et al. 1988), soil fertility (Winder and Van Dyke 1990), and safety on the wide range of possible tree crops should also be considered. In situ field testing would be the best challenge for this fungus. Plants which have not been transplanted will probably display a different level of susceptibility. Finally, the susceptibility of perennial forms of the weed should be investigated, because the regenerative capacity of rhizomes can adversely affect efficacy (Winder and Van Dyke 1990). Although mature perennial plants eventually become the dominant form of fireweed in a stand, seedlings and rosettes of the type susceptible to $C$. dematium predominate in new clearings, where the primary infestation usually originates from wind-borne seeds (Haeussler and Coates 1986). Control efforts with $C$. dematium could therefore be concentrated in the growing seasons following the occurrence of a clear-cut or burn until conifers become established. Although more study is needed to remove technical barriers and optimize its performance, an opportunity exists to develop $C$. dematium into a silvicultural tool for the management of fireweed.

\section{ACKNOWLEDGEMENTS}

Financial support from the Ministère de I'Environnement du Québec, the Centre Québécois de Valorisation de la Biomasse, and McGill University is acknowledged. We thank the personnel of the Ministère de l'Énergie et des Ressources du Québec 
for assistance in field surveys, and Lucie Pinsonnault, Guy Tourigny, and François Blain for technical assistance.

\section{REFERENCES}

Addeman, S. 1969. The generalized randomized block design. Am. Stat. 23: 35-36.

Anderson, R.N., and H.L. Walker. 1985. Colletotrichum coccodes: a pathogen of eastern black nightshade (Solanum ptycancthum). Weed Sci. 33: 902-905.

Anonymous. 1988. Pesticides recommandés par le Ministère de l'Agriculture, des Pêcheries, et de l'Alimentation. Gouvernement du Québec, M.A.P.A.Q., Québec. p. 290.

Boyette, C.D. 1987. Biocontrol of hemp sesbania [Sesbania exaltata (Raf.) Cory.] by an induced host range alteration of Alternaria crassa. Weed Sci. Soc. Am. 27: 48 (Abstract).

Boyette, C.D. 1991. Host range and virulence of Colletotrichum truncatum, a potential mycoherbicide for hemp sesbania (Sesbania exaltata). Plant Dis. 75: 62-64.

Boyette, C.D., G. Templeton, and R. Smith, Jr. 1979. Control of winged waterprimrose (Jussiae decurrens) and northern jointvetch (Aeschynomene virginica) with fungal pathogens. Weed Sci. 27: 497-501.

Broderick, D.H. 1990. The biology of Canadian weeds. 93. Epilobium angustifolium L. (Onagraceae). Can. J. Plant Sci. 70: 247259.

Campbell, R.A. 1990. Herbicide use for forest management in Canada: where we are and where we are going. For. Chron. 66: 355365.

Conner, J., A. Gray, T. Reynolds, and P. Waterman. 1989. Anthracene and chromone derivatives in the exudate of Aloe rabaiensis. Phytochemistry (Oxf.) 28: 35513553.

Daigle, D.J., W.J. Connick, Jr., P.C. Quimby, J. Evans, B. Trask-Morrell, and F.E. Fulgham. 1990. Invert emulsions: carrier and water source for the mycoherbicide, Alternaria cassiae. Weed Technol. 4: 327331.

de Jong, M.D., P.C. Scheepens, and J.C. Zadoks. 1990. Risk analysis for biological control: a Dutch case study in biocontrol of Prunus serotina by the fungus Chondrostereum purpureum. Plant Dis. 74: 189194.

Durand, H. 1923. Wildflowers and ferns: in their homes and our gardens. G.P. Putnam's sons, New York. p. 190.

Farr, D.F., G.F. Bills, G.P. Chamuris, G.P., and A.Y. Rossman. 1989. Fungi on plants and plant products in the United States. Am. Phytopathol. Soc., St. Paul, MN. p. 317-318.
Ginns, J.H. 1986. Compendium of plant disease and decay fungi in Canada, 19601980. Publication no. 1813, Agriculture Canada, Ottawa, ON. p. 89.

Grover, R.K. 1971. Participation of host exudate chemicals in appressorium formation by Colletotrichum piperatum. Pages $510-$ 518 in T.F. Preece (ed.), Ecology of leaf surface organisms. Academic Press, New York.

Haeussler, S., and D. Coates. 1986. Autecological characteristics of selected species that compete with conifers in British Columbia: a literature review. F.R.D.A. Report 001, Governments of Canada and British Columbia. Victoria, BC. p. 65-69.

Hildebrand, P., and K. Jensen. 1991. Potential for the biological control of St. John'swort (Hypericum perforatum) with an endemic strain of Colletotrichum gloeosporioides. Can. J. Plant Pathol. 13: 60-70.

Hultén, E. 1968. Flora of Alaska and neighboring territories: a manual of the vascular plants. Stanford Univ. Press, Stanford, CA. p. 686.

Jobidon, R. 1991. Some future directions for biologically based vegetation control in forestry research. For. Chron. 67: 514-519.

Lambert, J.L., J.R. Boyle, and W.R. Gardner. 1969. The growth response of a young pine plantation to weed removal. Can. J. For. Res. 2: 152-159.

Louise, I., A. Chew, and G. Lim. 1988. Influence of spore density and extracellular conidial matrix on spore germination in Colletotrichum capsici. Trans. Br. Mycol. Soc. 91: 694-697.

Mabusela, W., A. Stephen, and M. Botha. 1990. Carbohydrate polymers from Aloe ferox leaves. Phytochemistry (Oxf.) 29: 35553558.

Marie-Victorin, F. 1964. Flore laurentienne. Les Presses de I'Université de Montréal, Montréal, OC. 927 pp.

McRae, C.F., and G.R. Stevens. 1990. Role of conidial matrix of Colletotrichum orbiculare in pathogenesis of Xanthium spinosum. Mycol. Res. 94: 890-896.

Mortensen, K. 1988. The potential of an endemic fungus, Colletotrichum gloeosporioides, for biological control of round-leaved mallow (Malva pusilla) and velvetleaf ( $\mathrm{Abu}$ tilon theophrasti). Weed Sci. 36: 473-478.

Nicholson, R.L., J. Hipskind, and M. Hanau. 1989. Protection against phenol toxicity by the spore mucilage of Colletotrichum graminicola, an aid to secondary spread. Physiol. Mol. Plant Pathol. 35: 243-252.

Nishimura, S., and K. Kohmoto. 1983. Roles of toxins in pathogenesis. Pages 137-157 in J. Daly and B. Deveral (eds.), Toxins and plant pathogenesis. Academic Press, New York. 
SAS Institute Inc. 1988. SAS/STAT User's guide: release 6.03. SAS Institute Inc., Cary, NC. $1029 \mathrm{pp}$.

Sinclair, W.A., H.H. Lyon, and W.T. Johnson. 1987. Diseases of trees and shrubs. Cornell Univ. Press, Ithaca, NY. 574 pp.

Smith, R.J. Jr. 1986. Biological control of northern jointvetch (Aeschynomene virginica) in rice (Oryza sativa) and soybeans (Glycine max)- a researcher's view. Weed Sci. 34 (Suppl. 1): 17-23.

Sparace, S.A., L.A. Wymore, R. Menassa, and A.K. Watson. 1991. Effects of the Phomopsis convolvulus conidial matrix on conidia germination and the leaf anthracnose disease of field bindweed (Convolvulus arvensis). Plant Dis. 75: 1175-1179.

Steel, R.G.D., and J.H. Torrie. 1980. Principles and procedures of statistics: a biometrical approach. McGraw Hill Book Co., New York. p. 471.

Trujillo, E., F. Latterell, and A. Rossi. 1986. Colletotrichum gloeosporioides, a possible biological control agent for Clidemia hirta in Hawaiian forests. Plant Dis. 70: 974-976.

Tuite, J. 1969. Plant pathological methods: fungi and bacteria. Burgess Pub. Co., Minneapolis, MN. 239 pp.
Wagner, R.G., and J.C. Zasada. 1991. Integrating plant autecology and silvicultural activities to prevent forest vegetation management problems. For. Chron. 67: 506513.

Wall, R.E. 1985. The role of disease in removal of weed species from developing forest stands. Pages 673-676 in E.S. Delfosse (ed.), Agric. Can., Ottawa, Proc. VI Int. Symp. Biol. Contr. Weeds, Aug. 1984, Vancouver.

Wall, R.E. 1990. The fungus Chondrostereum purpureum as a silvicide to control stump sprouting in hardwoods. N.J. Appl. For. 7: 17-19.

Wall, R.E., and S.F. Shamoun. 1990. Experiments on vegetation control with native pathogenic fungi in the Southern Interior of British Columbia. F.R.D.A. Report 134. Governments of Canada and British Columbia, Victoria, BC. 18 pp.

Winder, R.S., and C.G. Van Dyke. 1990. Pathogenicity, virulence, and biocontrol potential of two Bipolaris sp. on johnsongrass. Weed Sci. 38: 89-94.

Wymore, L.A., C. Poirier, A.K. Watson, and A.R. Gotlieb. 1988. Colletotrichum coccodes, a potential bioherbicide for control of velvetleaf (Abutilon theophrasti). Plant Dis. 72: $534-538$. 